\title{
New forces influencing savanna conservation: increasing land prices driven by gentrification and speculation at the landscape scale
}

\author{
Peter Tyrrell ${ }^{1,2,3^{*}}$, Robin Naidoo ${ }^{4,5}$, David W Macdonald ${ }^{1}$, and Johan T du Toit ${ }^{6,7}$
}

Land transformation reduces biodiversity and regional sustainability, with land price being an indicator of the opportunity cost to a landowner of resisting land conversion. However, reliable spatially explicit databases of current land prices are generally lacking in developing countries. We used tools from data science to scrape 1,487 georeferenced land prices in southern Kenya from the internet. Prices were higher for land near cities and in areas of high agricultural productivity, but also around the Maasai Mara National Reserve. Predicted land prices ranged from US\$662 to US\$4,618,805 per acre. Land speculation associated with expanding urbanization increases the opportunity and acquisition costs of maintaining conservation buffer zones, corridors, and dispersal areas. However, high land values are also found adjacent to a world-famous tourist destination. Profit-driven turnover of ownership, subdivision, and transformation of land is occurring at a rapid pace in southern Kenya, to the detriment of savanna biodiversity and the sustainability of the pastoral social-ecological system.

Front Ecol Environ 2021; doi:10.1002/fee.2391

Dsingen espite rising global concern over biodiversity loss and declining environmental sustainability, current conservation expenditures remain inadequate (Waldron et al. 2013). Strategic prioritization of conservation interventions requires spatially explicit data on economic factors that threaten biodiversity and ecosystem function so that limited funds can be allocated most efficiently (Naidoo et al. 2006; Armsworth 2014). This applies particularly to biodiverse areas where land acquisition costs - the costs of full or partial transfers of land including leases, short-term rentals, and management rights are unknown and land users have freehold or leasehold tenure (Ando et al. 1998; Naidoo et al. 2006). Dependent on acquisition costs and willing buyers, property sales of undeveloped land often occur, and can result in its transformation into states with lower biodiversity and impaired ecosystem function (Sage 2019). Alternatively, if landowners maintain their land in states that conserve biodiversity and ecosystem services, they might forgo opportunities to adopt alternative and potentially more profitable land uses, such as crop and livestock production (Osano 2005; Norton-Griffiths and Said 2009).

In many regions of the world where wildlife conservation is of particular importance, net agricultural returns are usually higher than the current economic or social returns from

\footnotetext{
${ }^{1}$ Wildlife Conservation Research Unit, Department of Zoology, University of Oxford, Recanati-Kaplan Centre, Tubney House, Tubney, UK; ${ }^{2}$ South Rift Association of Landowners, Nairobi, Kenya; ${ }^{3}$ Department of Geography and Environmental Studies, University of Nairobi, Nairobi, Kenya ${ }^{*}$ peterdavidtyrrell@gmail.com); ${ }^{4}$ WWF-US, Washington, DC; ${ }^{5}$ Institute for Resources, Environment, and Sustainability, University of British Columbia, Vancouver, Canada; ${ }^{6}$ Department of Wildland Resources, Utah State University, Logan, UT; ${ }^{7}$ Mammal Research Institute and Department of Zoology and Entomology, University of Pretoria, Hatfield, South Africa
}

wildlife, resulting in opportunity costs (these are costs of foregone opportunities; that is, they are a measure of what could have been gained via the next-best use of a resource had it not been put to the current use) to landowners that eventually drive land-use changes (du Toit et al. 2017). Consequently, protected areas (PAs) are typically situated in regions with the lowest agricultural potential, not the highest biodiversity (Venter et al. 2017); moreover, PAs that have been established in agriculturally productive regions are increasingly isolated within hard boundaries (that is, surrounded by land-use incompatible with wildlife conservation) or eroding buffer areas (Newmark 2008). Outside of PAs, land transformation represents one of the major drivers of global biodiversity decline in general (Sage 2019) and local declines in large mammal populations in particular (Newmark 2008). Economic costs are therefore increasingly incorporated into conservation planning, and spatially explicit data to estimate these costs are essential for developing a systematic planning framework (Naidoo et al. 2006; Adams et al. 2019). One key metric is the price of land, which not only represents the acquisition cost of the land but can also indicate the expected discounted future revenues from the land once it has been purchased (although not necessarily the net profit). Land prices therefore can provide a basis for estimating opportunity costs across alternative land-use options (Osano 2005). In situations where either the economic or the intrinsic value of wildlife and nature is high, these values could overcome the opportunity costs of conservation even to the extent of inflating local land prices (Gibbons et al. 2014).

Calculation of spatially explicit estimates of land prices in developing countries is challenging, however, due largely to the lack of reliable databases containing information on the current price of land for sale (Naidoo et al.2006). In the absence of 
more complete datasets, one common practice is to select proxies of economic forces that affect biodiversity at the landscape scale and then extrapolate across a region of interest. However, proxies can be arbitrarily applied and may be at the wrong spatial resolution required for conservation planning, or only weakly supported by comprehensive economic data (Armsworth 2014). A potential solution is to build a spatially explicit database of actual land prices, thereby providing a reliable basis for mapping spatial heterogeneity in costs and benefits to inform systematic conservation planning, and for providing inference on the drivers of land price (Osano 2005; Naidoo et al. 2006). Here, we report on the results of an exercise to achieve this goal for a region in Africa world-renowned for its biodiversity.

Maasai pastoralists have long coexisted with diverse wildlife communities and are the traditional land custodians across vast extents of East African savanna, but ongoing changes to policy, governance systems, demography, and livelihoods are leading to wide-scale land transformation in this region (Mwangi and Ostrom 2009; Veldhuis et al. 2019). In response to land conversion in Kenya, several conservancies - areas where landowners set aside their land for the protection of biodiversity - have been formed as a mechanism for preventing land transformation and conserving habitats for diverse and abundant wildlife communities (Western et al. 2020). These conservancies are often created through land leasing by ecotourism operators or conservation nongovernmental organizations, but their long-term sustainability is threatened by mounting opportunity and acquisition costs (Norton-Griffiths and Said 2009). To investigate this threat, we estimated the acquisition costs of land across southern Kenya using tools from the field of data science to "scrape" land asking prices from internet advertisements, and then built a generalized additive model (GAM) with environmental and anthropogenic covariates to map the spatial variation in land asking prices (hereafter, "land prices"). Areas with high predicted land prices are likely to undergo land transformation and be hotspots of future biodiversity losses. We then compared predicted land prices to the Human Footprint, a cumulative threat map indicative of current anthropogenic pressures on biodiversity (Venter et al. 2016a; Di Marco et al. 2018), to determine where current and future impacts on biodiversity converge or diverge to help prioritize conservation action. Our analysis revealed profound economic threats to the sustainability of traditional social-ecological systems across East African savannas, where wide-scale conservation efforts must address the drivers of land transformation.

\section{Methods}

We focused on five counties covering $54,471 \mathrm{~km}^{2}$ in southern Kenya, including six government-run PAs that are supplemented by conservancies (Figure 1). This study area, which includes some of the richest biodiversity in
Africa and the highest mammalian diversity on Earth, also supports the highest abundance of pastoral livestock and wildlife in eastern and southern Africa (Ogutu et al. 2016).

Using the R package rvest (v3.5; R Core Team 2018), we scraped data from land-sale advertisements listed on the website of a major Kenyan newspaper (The Star; www.thestar.co.ke). This yielded 4,128 potential land sales in the study area, which were described by location, price, and area of the plot. Each location was then georeferenced (WebPanel 1) and, following data cleaning, a total of 1,487 land pricings were used in the analysis (WebFigure 1). All prices are presented in US\$ per acre, which is the unit of land area used in the region.

Spatially explicit data were obtained for nine potential predictors of land price, which were chosen for an a priori expectation of their effect on price (WebTable 1; WebFigure 2). In addition to variables related to the price of land relative to development, the potential yield of maize (Zea mays) was used as a proxy for the productivity of agricultural land. Distance to the nearest edge of the Maasai Mara National Reserve was also included because of its strong tourism industry, which pays lease fees to landowners for exclusive use for ecotourism and conservation that in turn may inflate land prices.

A GAM with a negative binomial logit link structure was used to model univariate smooths of all the predictor variables, with "land cover" added as a parametric term. Details are provided in WebPanel 1. Spatial autocorrelation and concurvity were checked and no issues were detected (WebFigures 5 and 6). The final model was then used to predict land prices across 54,472 cells at a $1-\mathrm{km}^{2}$ resolution in southern Kenya.

We used a comprehensive cumulative threat map, the recently updated Human Footprint (Venter et al. 2016b), to identify current threats to biodiversity (Figure 2) (WebPanel 1). To illustrate the costs of implementing large-scale conservation plans, we estimated the acquisition costs of land in two separate areas: (1) the Shompole-Olkiramatian region in the South Rift Valley, which is the only large wildlife refuge in southern Kenya not congruent with a government-operated PA (Tyrrell et al. 2017); and (2) an area encompassing the Nairobi National Park dispersal area and the remainders of the Athi-Kapiti dispersal areas, which historically supported abundant migratory wildlife but are now highly fragmented (Western and Gichohi 1993; Said et al.2016) and include two proposed corridors for wildlife movement (Ojwang' et al. 2017) (WebPanel 1; WebFigure 8).

\section{Results}

The 1,487 georeferenced potential land sales included in our analysis ranged in price per acre from $\$ 746$ to $\$ 7,293,221$ (WebFigure 1). Our GAM fit the data well (WebFigure 5) and explained $75.8 \%$ of the deviance (adjusted $R^{2}=0.674$ ) (full model details are provided in WebTables 2 and 3 as 


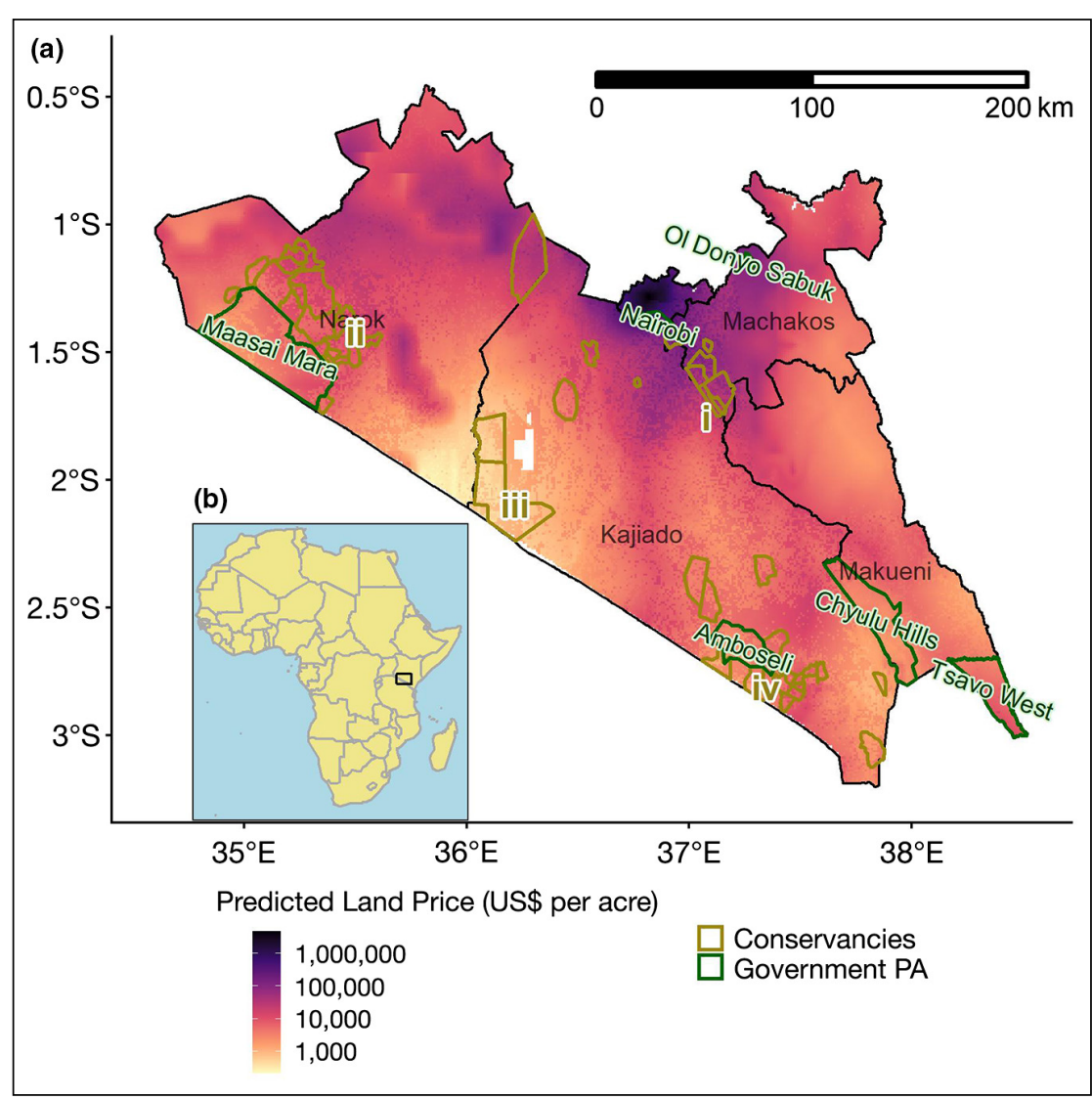

Figure 1. (a) Map of the predicted price of land (US\$ per acre) for the southern Kenyan counties of Kajiado, Narok, Makueni, Machakos, and Nairobi (covering 54,471 km²). The land price color scale was log-transformed. Kenya's government-operated protected areas (PAs) are outlined in dark green (Tsavo West National Park, OI Donyo Sabuk National Park, Nairobi National Park, Maasai Mara National Reserve, Chyulu Hills National Park, and Amboseli National Park); the operational private and community conservancies are outlined in beige. Conservancies are grouped into four administrative regions: (i) Athi-Kapiti, (ii) Maasai Mara, (iii) South Rift, and (iv) Amboseli. The predicted land price in central Nairobi is several orders of magnitude higher than that in the surrounding region. (b) Inset displaying the study region in southern Kenya (black rectangle) within the African continent.

Park, which had the lowest ( $\$ 2,778$ per acre). Of the conservancies, the Athi-Kapiti region had the highest median value ( $\$ 52,481$ per acre) followed by the Maasai Mara ( $\$ 10,896$ per acre), while the South Rift had the lowest ( $\$ 754$ per acre) (Figure 4).

\section{Discussion}

The values we predicted across $54,471 \mathrm{~km}^{2}$ of southern Kenya generated one of the few spatially explicit maps of land prices in a developing country. This revealed high spatial heterogeneity in per-acre land price (\$662 in a remote area, $\$ 4,618,805$ in central Nairobi; Figure 1). These prices represent both the acquisition cost of the land and an indicator of the opportunity cost of conservation to landowners, as commercial transactions of relatively undisturbed land indicate potential land transformations. Areas under traditional (pastoral) land use with relatively high or rapidly increasing land prices are therefore where biodiversity losses are most likely to occur and environmental sustainability is most at risk (Figure 2).

Although some caveats to the interpretation of these data exist (WebPanel 1), the overall results and the method we employed have several immediate applications for conservation planning and action. First, the Kenyan Government is actively seeking ways to offset the opportunity costs of wildlife to landowners. A task force has been charged with identifying corridors and dispersal areas that should be protected to the greatest extent possible from development, as part of a regional conservation master plan. To this end, land price data enable initial assessments of pres-

well as in WebFigure 4; the univariate smooths and parametric terms of the models are shown in Figure 3). The GAM response curves (Figure 3) revealed several trends: (1) as the distance from Nairobi increased, land price fell dramatically for the first $25 \mathrm{~km}$ and continued to decline to an asymptote at around $100 \mathrm{~km}$ from the city; (2) land prices were highest in areas with greater potential maize yields but only after a potential yield of 6 metric tons per hectare, below which land values were suppressed; (3) land prices were higher directly adjacent to the Maasai Mara; (4) land price decreased with distance from major roads; and (5) land price increased with increasing herbaceous land cover $(\beta=$ $0.652, P<0.001)$, cropland $(\beta=0.233, P=0.027)$, and urbanization $(\beta=0.243, P=0.021)$ (WebTable 3; Figure 3).

Government-operated PAs were not on the land market but we predicted their potential land prices as if they were. These included Nairobi National Park, which had the highest median value ( $\$ 284,418$ per acre), and Amboseli National ent and future threats to biodiversity through land transformation. For example, in the direct vicinity of Nairobi, there are both high current impacts on biodiversity (as indicated by a high human footprint) but also little chance of reversing these trends due to the high opportunity and acquisition costs (as indicated by the land price) (Figures 2 and 4). Notably, our research reveals that land price and current conservation impact do not covary in a simple linear relationship (Figure 2). For example, some areas, such as the Maasai Mara conservancies, have low current threats to biodiversity (as indicated by a low human footprint) yet may have a high threat of land conversions (as indicated by a higher land price) (Figures 2 and 4). Areas where current pressure and land prices are both low, such as the South Rift Valley and the Amboseli ecosystem, may have a high potential for proactive community-based conservation (Figures 2 and 4). The Shompole-Olkiramatian ecosystem in the South Rift Valley, for example, may require considerably less investment to overcome opportunity costs 


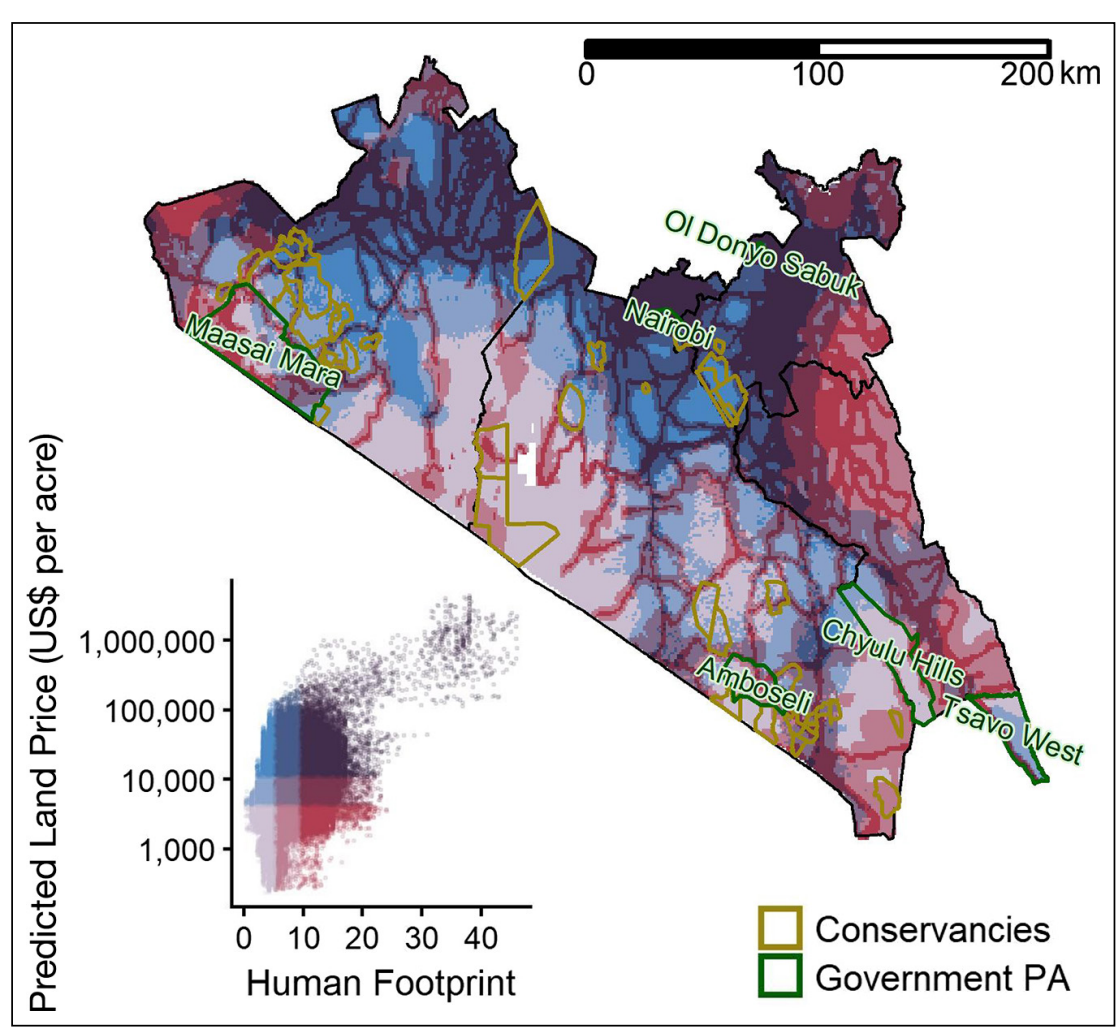

Figure 2. A bivariate plot of predicted land price (US\$ per acre) against the human footprint (Venter et al. 2016b). This compares the current impacts of development, infrastructure, and land use, as indicated by the human footprint (a scaled level of threat, ranging from 0 [no impact] to 50 [completely human-dominated urban systems]), against the potential impacts, as suggested by land price and its link to land sale and conversion. Note the low current impacts but high land prices (red) in the Maasai Mara region, around Nairobi, and along the main roads. Low impacts and low land prices (light blue) indicate areas with potential for community-based conservation, such as the South Rift Valley and the Amboseli region.

than the Nairobi-Athi-Kapiti ecosystem (Figure 4; WebFigure 8; see below). Second, this methodology provides a rapid, repeatable, and scalable procedure for collecting land price data where no regional databases exist, and allows comparisons with other regions of interest where online data are available. These patterns of changing land price and tenure are not exclusive to Kenya or the African savanna biome. Multiple terrestrial ecosystems, such as the Brazilian cerrado, face similar pressures and would benefit from a similar quantification of land price and its drivers (Reid et al. 2014; Rosa 2020). Third, this approach predicts costs at a scale relevant to local systematic conservation planning, rather than at aggregated administrative levels (Armsworth 2014). Finally, none of these estimates rely on data restricted to certain types of land sales but represent the actual asking price on the open market (Naidoo et al. 2006; Armsworth 2014). Conservation prioritization is usually based on arbitrary proxies of acquisition costs, and comparing priority areas identified by different datasets will be important for ensuring effective and efficient conservation action in the future.

Previous work on opportunity and acquisition costs in savanna ecosystems has focused on the forgone profit from agriculture as the main competing costs to wildlife-friendly land use (Norton-Griffiths and Said 2009; du Toit et al. 2017). In our analysis, we also found that agricultural potential was a factor but that it had a much smaller effect on the price of land in southern Kenya than did urban expansion and infrastructure development (Figure 3; WebFigure 7). Historically, wildlife-rich areas in southern Kenya were largely used by pastoral Maasai people for grazing their livestock, with land held under communal tenure. Facing economic and political pressures, most of these areas have now been privatized and subdivided (Mwangi and Ostrom 2009). The new landowners, who accrue few economic benefits from wildlife and have dwindling profits from livestock, have typically sold at least part of their land to partake in the cash economy (Rutten 1992). Subsequently, much of this land has been fenced, with the woody vegetation removed, burned, and sold as charcoal, and the land converted into agriculture or urban development, or held by speculators hoping for higher land prices (Rutten 1992; Kimani and Pickard 1998; Said et al. 2016). This trend of land subdivision and subsequent sale is ongoing across the region, and the price of land is likely to continue to increase as the human population and national economy both grow. As such, economic drivers are acting to contract the remaining areas of habitat for wildlife and rangeland for livestock, severing connectivity between wildlife subpopulations and threatening one of the most diverse assemblages of large mammal species on the planet (Ogutu et al. 2016; Said et al. 2016; WebFigure 9).

In the case of land close to Nairobi, where there is high demand for the development of housing estates and industrial parks, the outlook for biodiversity conservation is poor. Over the past 30 years, the Athi-Kapiti plains adjacent to Nairobi National Park have been subdivided into individual plots, and despite efforts to establish payments for ecosystem services within conservancies, wildlife populations have plummeted; at present, the park is little more than a remnant island of nature in a sea of development (Figure 2) (Said et al. 2016). The surrounding land now has a median sale value of $\$ 51,264$ per acre, offering a return on investment well above that received from wildlife conservation (Figure 4). Moreover, the land inside Nairobi National Park is potentially worth $\$ 282,961$ per acre, and maintaining that land as a national park therefore represents a considerable investment by the Kenyan government in protecting wildlife habitat. Conservation of the remaining dispersal areas adjacent to Nairobi National Park and in the Athi-Kapiti plains would now be virtually impossible through financial reasoning alone; our data suggest that the market-value purchase of 


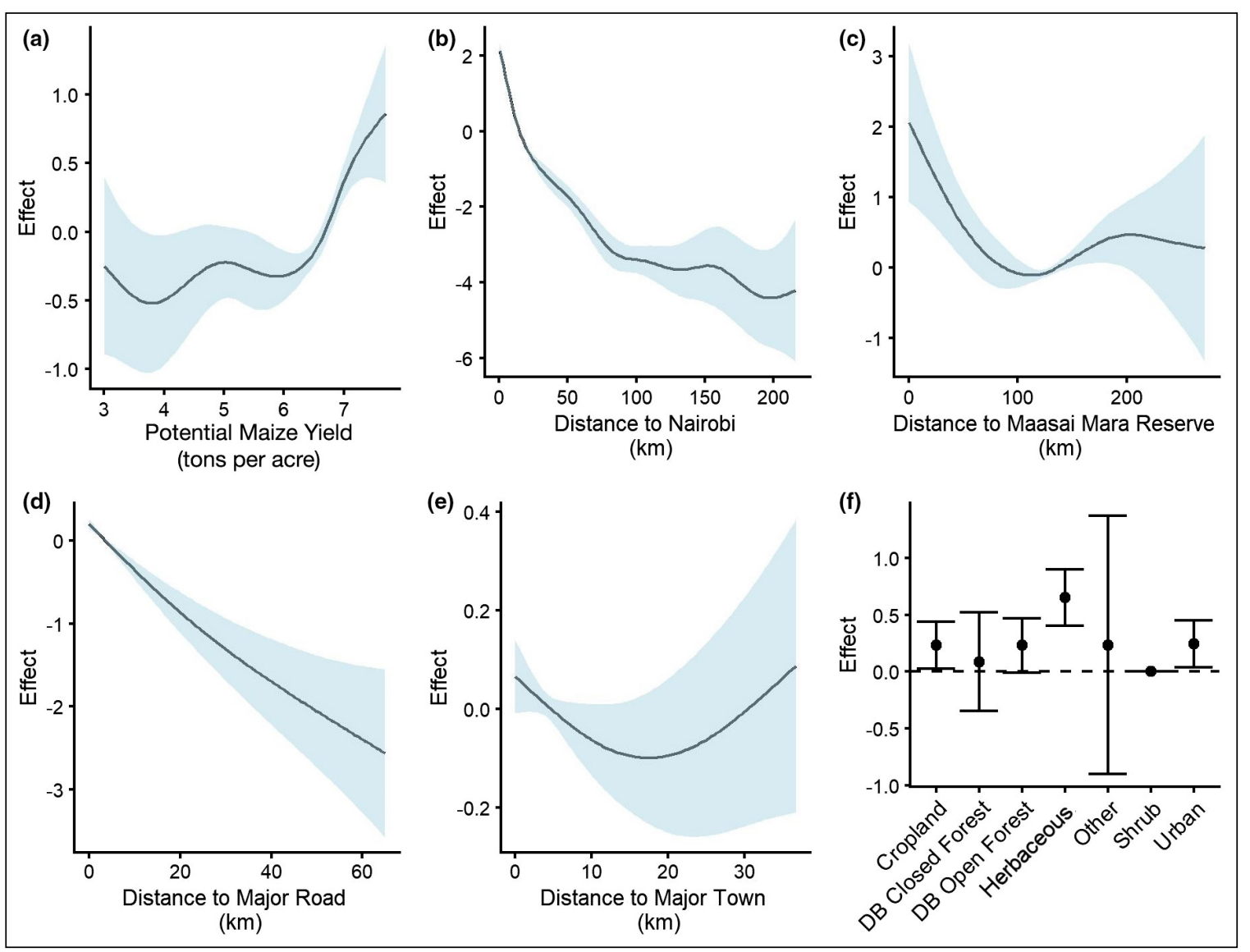

Figure 3. Generalized additive model smooths for the nonparametric terms included in the final model explaining land price in southern Kenya. The price of land per acre (effect size) was influenced by (a) the potential yield of maize (Zea mays, metric tons per acre); (b) distance to Nairobi (Kenya's capital city and largest commercial hub); (c) distance to the Maasai Mara (a world-famous tourist destination and a major contributor to the local and national economy); (d) distance to main roads; (e) distance to major towns; and (f) land cover (the shrub parametric term is used as the intercept - reference land cover with zero effect - for the model). DB = deciduous broadleaf. Blue shading in panels (a-e) indicates $95 \%$ confidence intervals (Cls). Error bars in panel ( $\mathrm{f}$ ) represent the $95 \% \mathrm{Cl}$ for the parametric land-cover terms. The probability of future urban expansion and population density were removed during penalization.

dispersal areas and corridors laid out in government plans for this area could cost as much as $\$ 40$ billion (WebFigure 8). We accept that some individual landowners might resist selling their land due to the traditionally high social and cultural values they attach to their land and wildlife, but the current scale and rate of industrial and urban development (Said et al.2016) make it unlikely that traditional values will be sufficient to maintain connectivity between the AthiKapiti plains and Nairobi National Park.

Our analysis also revealed that land prices increased with proximity to Maasai Mara National Reserve. Land for sale in this region is advertised for the development of tourism facilities, private holiday homes, and to protect and appreciate wildlife. The target market is nonlocal investors and wealthy individuals, which introduces the process of gentrification (WebPanel 2; WebFigure 9). Whether this will facilitate biodiversity conservation remains to be seen. Conservancies in this region, funded primarily by tourism and philanthropy, currently provide landowners with an average annual income of $\sim \$ 15$ per acre (MMWCA 2019). These payments come with the condition of maintaining the land in a state fit for wildlife conservation, which impedes land transformation, but the relatively high median land value of $\$ 10,895$ per acre (Figures 1 and 4) provides landowners with a strong financial incentive to sell, even with the added income accrued from tourism-based employment and livestock grazing schemes within conservancies. Proximity to a rich wildlife resource is inflating local land prices, similar to patterns observed elsewhere in the world (Gibbons et al. 2014), which could increase adjacent development and speculation, and make future investments in land and leases for conservancies more expensive (Armsworth et al. 2006).

\section{Conclusions}

Displacement of traditional subsistence pastoralists from land that is sold to wealthier investors from elsewhere (gentrification) and land transactions motivated by potential resale profits (speculation) are rapidly increasing in southern Kenya, with profound implications for the traditional Maasai socialecological system and the conservation of a global biodiversity treasure. We urge that land price trends be monitored across 


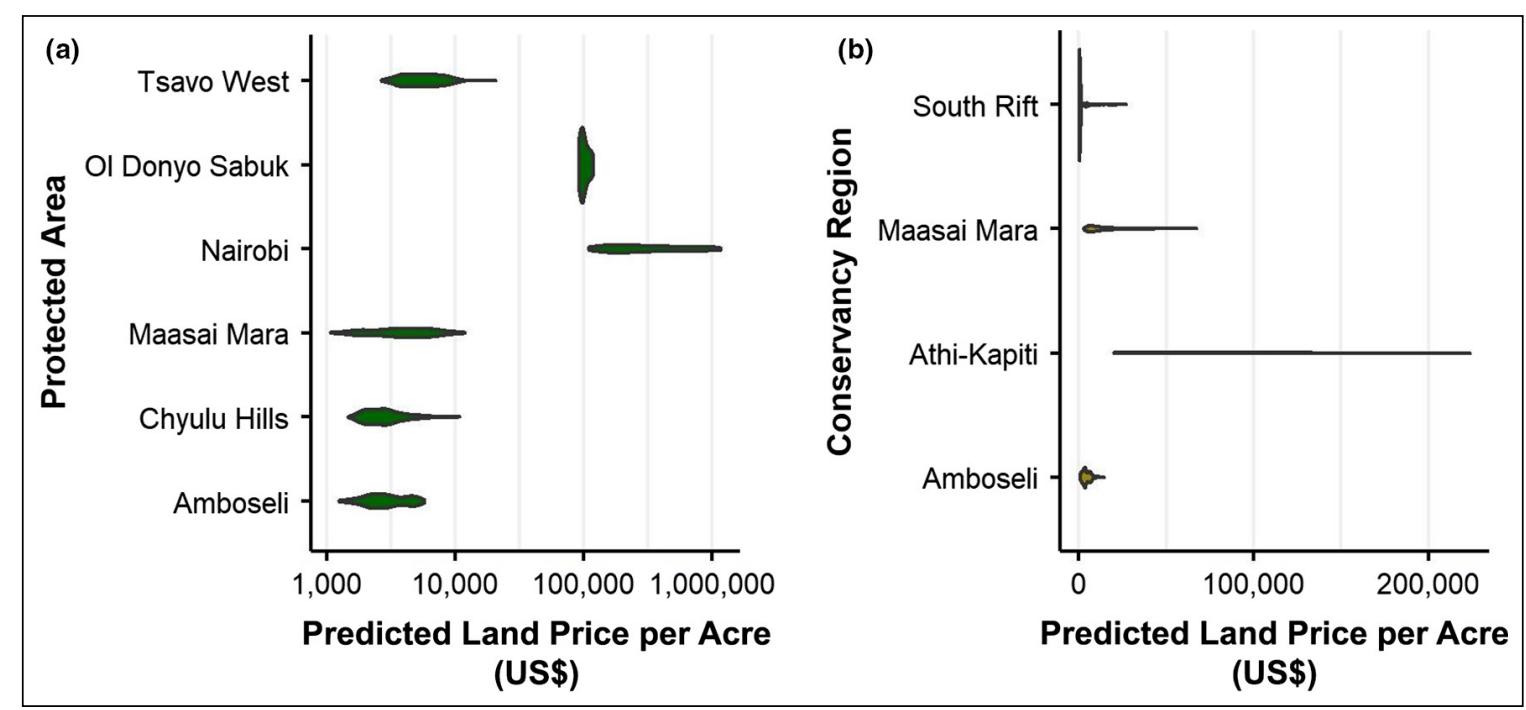

Figure 4. Violin plots showing the distributions of predicted land price per acre for (a) each of the government-run PAs and (b) each conservancy region. The outlines of the violin plots illustrate kernel probability density (that is, the width of the shaded area represents the proportion of the data located within). Note the difference in scale on the $\mathrm{x}$-axis; the $\mathrm{x}$-axis scale in (a) has been log-transformed to accommodate the higher land prices in Nairobi National Park and OI Donyo Sabuk National Park.

rangeland ecosystems and that bold and creative policies be introduced to enable landowners within these "working landscapes" to offset the opportunity costs of resisting land transformation (Norton-Griffiths and Said 2009; Kremen and Merenlender 2018). In particular, our findings underscore the importance of finding economic solutions to ensure the long-term sustainability of African wildlife, wildlands, and traditional pastoral systems (Western et al. 2020). Options include targeted government subsidies to private landowners, payments for ecosystem services, improved livestock management, restructured tourism revenue flows, incentives for domestic tourism, and innovative financial structures to enhance wildlife-based revenues to local households (Lindsey et al. 2020). In addition, extensive land-price mapping should be used to inform regional land-use planning, such as that already underway across Kenyan rangelands from both the bottom up (communities and conservancies) and top down (national and regional governments).

Under sustained population and economic growth, urbanization and land speculation will continue across African savannas - where much of the planet's remaining megafauna occur - and may influence the economic viability of wildlifefriendly landscapes (Newbold et al. 2015). Understanding these drivers of land transformation, and using this knowledge in a systematic conservation planning framework that optimizes conservation expenditure, will be vital for conserving biodiversity on enough land to achieve globally agreed conservation targets (Allan et al. 2019).

\section{Acknowledgements}

We thank A Balmford, A Waldron, and J Kamanga for detailed discussions on this topic, which helped form the ideas presented here. PT thanks the Cincinnati Zoo and Botanical Gardens and J Musgrove for their support.

\section{References}

Adams VM, Mills M, Weeks R, et al. 2019. Implementation strategies for systematic conservation planning. Ambio 48: 139-52.

Allan JR, Possingham HP, Atkinson SC, et al. 2019. Conservation attention necessary across at least $44 \%$ of Earth's terrestrial area to safeguard biodiversity. bioRxiv; doi.org/10.1101/839977.

Ando A, Camm J, Polasky S, and Solow A. 1998. Species distributions, land values, and efficient conservation. Science 279: 2126-28.

Armsworth PR. 2014. Inclusion of costs in conservation planning depends on limited datasets and hopeful assumptions. Ann NY Acad Sci 1322: 61-76.

Armsworth PR, Daily GC, Kareiva P, and Sanchirico JN. 2006. Land market feedbacks can undermine biodiversity conservation. $P$ Natl Acad Sci USA 103: 5403-08.

Di Marco M, Venter O, Possingham HP, and Watson JEM. 2018. Changes in human footprint drive changes in species extinction risk. Nat Commun 9: 4621.

du Toit JT, Cross PC, and Valeix M. 2017. Managing the livestockwildlife interface on rangelands. In: Briske DD (Ed). Rangeland systems: processes, management and challenges. Cham, Switzerland: Springer International.

Gibbons S, Mourato S, and Resende GM. 2014. The amenity value of English nature: a hedonic price approach. Environ Resour Econ 57: 175-96.

Kimani K and Pickard J. 1998. Recent ranch trends and implications of group ranch sub-division and fragmentation in Kajiado District, Kenya. Geogr J 164: 202-13.

Kremen C and Merenlender AM. 2018. Landscapes that work for biodiversity and people. Science 362: eaau6020. 
Lindsey P, Allan J, Brehony P, et al. 2020. Conserving Africa’s wildlife and wildlands through the COVID-19 crisis and beyond. Nat Ecol Evol 4: 1300-10.

MMWCA (Maasai Mara Wildlife Conservancies Association). 2019. State of Mara conservancies. Narok, Kenya: MMWCA.

Mwangi E and Ostrom E. 2009. Top-down solutions: looking up from East Africa’s rangelands. Environment 51: 34-45.

Naidoo R, Balmford A, Ferraro PJ, et al. 2006. Integrating economic costs into conservation planning. Trends Ecol Evol 21: 681-87.

Newbold T, Hudson LN, Hill SLL, et al. 2015. Global effects of land use on local terrestrial biodiversity. Nature 520: 45-50.

Newmark WD. 2008. Isolation of African protected areas. Front Ecol Environ 6: 321-28.

Norton-Griffiths M and Said MY. 2009. The future for wildlife on Kenya's rangelands: an economic perspective. In: du Toit JT, Kock $\mathrm{R}$, and Deutsch JC (Eds). Wild rangelands. Hoboken, NJ: WileyBlackwell.

Ogutu JO, Piepho H-P, Said MY, et al. 2016. Extreme wildlife declines and concurrent increase in livestock numbers in Kenya: what are the causes? PLoS ONE 11: e0163249.

Ojwang' GO, Wargute PW, Said MY, et al. 2017. Wildlife migratory corridors and dispersal areas: Kenya rangelands and coastal terrestrial ecosystems. Nairobi, Kenya: Government of the Republic of Kenya.

Osano PM. 2005. Estimating the opportunity costs of biodiversity conservation in Western Cape, South Africa (MSc thesis). Cape Town, South Africa: University of Cape Town.

R Core Team. 2018. R: a language and environment for statistical computing. Vienna, Austria: R Foundation for Statistical Computing.

Reid RS, Fernández-Giménez ME, and Galvin KA. 2014. Dynamics and resilience of rangelands and pastoral peoples around the globe. Annu Rev Env Resour 39: 217-42.

Rosa CA. 2020. Savannah for sale: is there hope for neotropical biodiversity on private, Brazilian properties? Anim Conserv; doi. org/10.1111/acv.12617.

Rutten MMEM. 1992. Selling wealth to buy poverty: the process of the individualization of landownership among the Maasai pasto- ralists of Kajiado District, Kenya, 1890-1990. Saarbrücken, Germany: Verlag Breitenbach.

Sage RF. 2019. Global change biology: a primer. Glob Change Biol 26: 3-30.

Said MY, Ogutu JO, Kifugo SC, et al. 2016. Effects of extreme land fragmentation on wildlife and livestock population abundance and distribution. J Nat Conserv 34: 151-64.

Tyrrell P, Russell S, and Western D. 2017. Seasonal movements of wildlife and livestock in a heterogenous pastoral landscape: implications for coexistence and community based conservation. Global Ecol Conserv 12: 59-72.

Veldhuis MP, Ritchie ME, Ogutu JO, et al. 2019. Cross-boundary human impacts compromise the Serengeti-Mara ecosystem. Science 363: 1424-28.

Venter O, Magrach A, Outram N, et al. 2017. Bias in protected-area location and its effects on long-term aspirations of biodiversity conventions. Conserv Biol 32: 127-34.

Venter O, Sanderson EW, Magrach A, et al. 2016a. Sixteen years of change in the global terrestrial human footprint and implications for biodiversity conservation. Nat Commun 7: 12588.

Venter O, Sanderson EW, Magrach A, et al. 2016b. Global terrestrial Human Footprint maps for 1993 and 2009. Scientific Data 3: 160067.

Waldron A, Mooers AO, Miller DC, et al. 2013. Targeting global conservation funding to limit immediate biodiversity declines. $P$ Natl Acad Sci USA 110: 12144-48.

Western D and Gichohi H. 1993. Segregation effects and the impoverishment of savanna parks: the case for ecosystem viability analysis. Afr J Ecol 31: 269-81.

Western D, Tyrrell P, Brehony P, et al. 2020. Conservation from the inside-out: winning space and a place for wildlife in working landscapes. People and Nature 2: 279-91.

\section{Supporting Information}

Additional, web-only material may be found in the online version of this article at http://onlinelibrary.wiley.com/ doi/10.1002/fee.2391/suppinfo 